\title{
Application of dried distillers grains with solubles (DDGS) as a replacer of soybean meal in broiler chickens feeding
}

Monika Łukasiewicz', Dorota Pietrzak², Jan Niemiec', Jan Mroczek² and Monika Michalczuk ${ }^{1}$

${ }^{1}$ Faculty of Animal Science, ${ }^{2}$ Faculty of Food Technology, Warsaw University of Life Sciences, Warsaw, Poland

\begin{abstract}
Contemporarily, the production of high-grade ethyl alcohol enables obtaining dried distillers decoction that contains post-fermentation residues of cereal grains, solubles as well as yeast cells and their metabolites multiplied in the fermentation process, which makes that product applicable also in poultry feeding. Experiments were conducted on 540 broiler chickens of COBB 500 line. One-day chicks were randomly allocated to 3 nutritional groups: $\mathrm{K}, \mathrm{D}_{1}$ and $\mathrm{D}_{2^{\prime}}$ each group consisted of 6 replicates of 30 birds. The factor that differentiated the groups was the content of dried wheat decoction in the starter type feed mixture $(5 \%$ and $7 \%$ ). Production results (individual body weight, feed intake and mortality) of the birds were controlled in a 42-day rearing period. On the 42nd day of rearing, 6 male and 6 female chickens from each group were chosen for slaughter that had body weights similar to the average of each group according to gender. The aim of this study was to determine experimentally whether the by-product of ethanol production is suitable for replacing soybean meal in feeding broiler chickens. The application of the wheat decoction had no negative effect on production results of the chickens. The birds fed a mixture with a higher content of dried distillers grains with solubles (DDGS) were characterised by a similar body weight and better feed conversion ratio compared to the control birds. A properly-balanced (fibre, energy, amino acids) nutritional dose of the dried wheat decoction may be used as a good energy-protein component in feed mixtures for broilers. It is a rational means of DDGS management which is, simultaneously, a cheaper substitute for soybean meal.
\end{abstract}

Keywords: broiler, feeding, DDGS, meat quality

\section{Introduction}

Dried distillers grains with solubles (DDGS) are a by-product of the spirit industry and of bioethanol production. They are obtained as a result of multi-stage concentration, and then, long-lasting drying of cereal mash, earlier deprived of ethyl alcohol. These products are constituted by components from initial raw material, being insensitive to fermentation (non-starch carbohydrates, protein, fat, ash and others), and biomass of the multiplied yeasts. Dried grains of cereal distillers are rich in protein, exogenous amino acids, B-group vitamins, biotin and mineral compounds, including phosphorus (Koreleski \& Świątkiewicz 2006, Thacker \& Widyaratne 2007, Min et al. 2008). The process of yeast fermentation results in the synthesis of microbiological phytase and, therefore, the availability of phosphorus in the 
discussed products is considerably greater than in other vegetal feeds (Martinez Amezcua et al. 2004, Lumpkins \& Batal 2005). It is especially important in feeding broiler chickens which due to a high growth are characterised by high demand for this element. It is also important from the ecological viewpoint, because the DDGS-containing mixtures enable a lower intake of dietary phosphates, owing to which the release of phosphorus to the environment is minimised (Koreleski \& Świątkiewicz 2006).

The content of nutrients in a product is diversified and depends, inter alia, on the raw material used for processing, quantity of yeast biomass and production technology of decoction. The availability of nutritional components in DDGS is greatly determined by the method of drying which affects the denaturation of protein and availability of exogenous amino acids. In recent years, owing to the use of the drying process under more moderate conditions, the nutritive value of the discussed decoctions has been considerably improved; they have been more and more frequently utilised in animal nutrition, also in Poland (Koreleski \& Świątkiewicz 2006). Most of the distiller's dried grains are produced in the Northern America, mainly from maize. In Europe, DDGS is manufactured from wheat and rye (Brzóska 2009).

In many countries, including Poland, investigations have been conducted on the possibility of applying DDGS in feed mixtures for various animal species, including broiler chickens (Nyachoti et al. 2005, Świątkiewicz \& Koreleski 2007, Thacker \& Widyaratne 2007, Wang et al. 2007, Świątkiewicz \& Koreleski 2008). Results of the studies indicate that a part of soybean meal in a feed mixture may be replaced by DDGS without lowering production results. Caution should, however, be exercised to appropriate balancing of the diet in respect of amino acid composition and energy and in respect of ensuring quantities of minerals and vitamins that will cover birds' demands.

The aim of the reported experiment was to verify the suitability of DDGS remaining after ethanol production as a soybean meal replacer in the feeding of COBB 500 broiler chickens, and also to define how its application affected proximate chemical composition and technological properties of meat, as well as to determine fatty acid profile in abdominal fat. No information about influence of DDGS on the quality of chicken meat and fat was found in the available literature.

\section{Material and methods}

The research was conducted on 540 broiler chickens of COBB 500 line kept on litter until 42nd day of life in standard zoohygienic conditions. One-day chicks were at random allocated to 3 nutritional groups: $K, D_{1}$ and $D_{2}$. Each group consisted of 6 repetitions, counting 30 birds each. During the initial rearing period, for 21 days, the starter and then, grower (until the 35th day) and finisher (up to the 42nd day) mixtures were administered to the birds. The composition of the experimental mixtures is given in Table 1. Their content of DDGS was a discriminating factor. Before the commencement of the experiment, the level of basic nutritional components was determined in the feed mixtures and in the decoction (AOAC 1995).

During the experiment body weight of the birds (on the 21st, 35th and 42nd day) and mortality were controlled. Finally, the feed conversion ratio per $1 \mathrm{~kg}$ of body weight gain (FCR) and European yield index were calculated according to the following formula: 
$\frac{\text { body weight }(\mathrm{kg}) \times \text { survivability }(\%)}{\text { age (days) } \times \text { feed intake in total per one bird }(\mathrm{kg})} \times 100$

On the 42th day of rearing, 6 male and 6 female chickens were selected from each group for slaughter, with the body weight similar to the mean body weight of the respective group. The carcasses of the chickens were cooled down by air at a temperature of $4^{\circ} \mathrm{C}$ for $24 \mathrm{~h}$ and dissected. Dressing percentage was calculated and the contribution of the following muscles: breast muscles, leg muscles, abdominal fat and offal in the carcass were determined. For analytical tests, 6 samples from leg muscles and 6 samples from breast muscles of the chickens were prepared from each nutritional group (without sex division into). The samples were averaged by mixing the same quantities of disintegrated meat. Next, $48 \mathrm{~h}$ after slaughter, the following determinations were carried out: $\mathrm{pH}$ - according to PN-ISO 2917, water holding capacity - by centrifuge method according to Wierbicki et al. (1962), thermal drip (30 g of disintegrated meat was heated in a beaker, covered with the self-sticking polyethylene film in a water bath at a temperature of $72^{\circ} \mathrm{C}$ for $30 \mathrm{~min}$ ) and also, proximate chemical composition (water, protein, fat and ash content) by standard methods (AOAC 1995). The material was comminuted and determined for fatty acid profile by means of gas chromatography (PN-ISO 5509:1996; PN-ISO 5508:1996) using a capillary column BXP 70 (SGE Analytical Science, Melbourne, Australia) with the length of $50 \mathrm{~m}$, internal diameter of $0.25 \mathrm{~mm}$ and phase thickness of $0.25 \mu \mathrm{m}$. The thiobarbituric acid (TBA) index (Shahidi 1990) was determined in order to define the oxidation changes $72 \mathrm{~h}$ after slaughter of the chickens, 7 days after storage of the samples in refrigeration conditions $\left(4-6^{\circ} \mathrm{C}\right)$ and after 56 days of storage in frozen state $\left(-18^{\circ} \mathrm{C}\right)$. The results were statistically developed by variance analysis, calculated by the least square method in a statistical programme SPSS 14.0 PL for Windows (SPSS Inc., Chicago, IL, USA).

Table 1

Composition and nutritional value of feeding, $\%$

\begin{tabular}{lccccccc}
\hline & \multicolumn{3}{c}{ Starter } & \multicolumn{2}{c}{ Grower } & \multicolumn{2}{c}{ Finisher } \\
& $\mathrm{K}$ & $\mathrm{D}_{1}$ & $\mathrm{D}_{2}$ & $\mathrm{~K}$ & $\mathrm{D}_{1} / \mathrm{D}_{2}$ & $\mathrm{~K}$ & $\mathrm{D}_{1} / \mathrm{D}_{2}$ \\
\hline Maize & 23.0 & 23.0 & 23.0 & 17.4 & 18.0 & 20.0 & 20.0 \\
Wheat & 34.0 & 34.9 & 34.0 & 44.0 & 39.7 & 44.1 & 40.5 \\
Soybean meal 46\% & 31.0 & 26.0 & 24.8 & 29.0 & 23.0 & 26.4 & 20.3 \\
Distillers dried grains & - & $\mathbf{5 . 0}$ & $\mathbf{7 . 0}$ & - & $\mathbf{9 . 5}$ & - & $\mathbf{9 . 5}$ \\
Wheat middlings & 1.0 & - & - & - & - & - & - \\
Soybean oil & 3.6 & 3.6 & 3.6 & 5.0 & 5.0 & 5.3 & 5.3 \\
Limestone & 1.4 & 1.4 & 1.4 & 0.6 & 0.6 & 0.2 & 0.2 \\
Premix & 6.0 & 6.0 & 6.0 & 4.0 & 4.0 & 4.0 & 4.0 \\
Calculated composition & & & & & & & \\
$\quad$ ME (MJ/kg) & 12.6 & 12.5 & 12.4 & 12.8 & 12.8 & 13.4 & 13.1 \\
Crude protein & 19.5 & 19.5 & 19.5 & 19.3 & 19.3 & 18.4 & 18.4 \\
Crude fibre & 3.7 & 4.0 & 4.2 & 3.6 & 4.5 & 3.5 & 4.4 \\
Fat & 5.7 & 5.8 & 5.8 & 6.8 & 7.1 & 7.2 & 7.4 \\
Lysine & 1.2 & 1.2 & 1.2 & 1.2 & 1.2 & 1.0 & 1.0 \\
Methionine + cystine & 0.6 & 0.6 & 0.6 & 0.6 & 0.6 & 0.6 & 0.6 \\
Ca total & 0.94 & 0.94 & 0.94 & 0.90 & 0.90 & 0.87 & 0.87 \\
Pavailable & 0.50 & 0.50 & 0.50 & 0.45 & 0.45 & 0.42 & 0.42 \\
\hline
\end{tabular}




\section{Results}

The content of nutrients in the experimental dried wheat distillers grains was as follows (in \%): dry matter - 95.2, crude protein - 32.7, crude fat - 5.3, crude fibre - 14.6, and crude ash -2.16 . The level of metabolisable energy calculated according to respective equations (European Table 1989) amounted to $8.47 \mathrm{MJ} / \mathrm{kg}$. The nutritive and energetic value of the feed mixtures, applied in the experiment, was given in Table 1.

Body weight of the chickens on the 21st day of rearing ranged from 1005.1 to $1023.6 \mathrm{~g}$ on average, whereas on the $42 \mathrm{nd}$ day of rearing from 2729.5 to $2794.9 \mathrm{~g}$. Body weight of the males, fed the diet with the addition of DDGS (groups $D_{1}$ and $D_{2}$ ) was lower in comparison to that of the males from the control group (K), In turn, the body weight of the females was equal in all feeding groups on the 35th as well as on the 42nd day of life (Table 2). Feed intake in the experimental groups of the chickens $\left(D_{1}\right.$ and $\left.D_{2}\right)$ was similar to that of the control group. However, a tendency for a decreasing feed intake along with the increasing DDGS content in the feed mixture (Table 3) was observed. Mortality in the particular feeding groups amounted to $3.0-5.5 \%$ and the lowest mortality rate was found in the chickens from $D_{1}$ group (3.0\%). This group was also characterised by the lowest number of dead chickens at the end of the rearing period as a result of sudden death syndrome (SDS). The European yield index was the highest in the chickens fed the diet with the higher DDGS addition $\left(D_{2}\right)$ reaching 348 , while the lowest one was found in the control group $(K)-341$. The application of DDGS in the chicken diet did not affect significantly the dressing percentage nor the contribution of breast and leg muscles in carcasses. Abdominal fat content amounted to 1.76-1.93\% (Table 4). No significant differences were found in offal content in carcasses, depending on feed composition (Table 4).

The chemical composition of breast muscles of the chickens from the control group and of these fed the diet with DDGS addition was very similar (Table 5). The leg muscles of the chickens from experimental groups $\left(D_{1}\right.$ and $\left.D_{2}\right)$ contained significantly less water (by $0.3-1.3 \%$ in average) and more fat (by $1.2 \%$ in average) as compared to the muscles of the chickens from the control group (K). Moreover, protein content in the leg muscles of the chickens from $D_{2}$ group was significantly higher as compared to the chickens from the remaining nutritional groups (by $0.5-1.0 \%$, on average). Table 6 presents results of the analysis of physicochemical traits of breast and leg muscles. According to these result, it may be stated that the application of DDGS had no significant effect on $\mathrm{pH}$ value, water holding capacity nor thermal drip amount in the meat. Irrespectively of the level of DDGS addition to the feed mixtures, breast muscles of the chickens, as compared to leg muscles, were characterised by a lower pH value (by ca. 0.3-0.4 units), worse water holding capacity and ca. twice lower amount of thermal drip.

The application of DDGS in the feed mixtures had no significant influence on fatty acid profile in the abdominal fat (Table 7). On the other hand, one should pay attention to a relatively high contribution of polyunsaturated fatty acids (PUFA) $(31.8-32.5 \mathrm{~g} / 100 \mathrm{~g})$ and especially of PUFA n-3 $(2.9 \mathrm{~g} / 100 \mathrm{~g})$. Oxidative stability of abdominal fat in the chickens was evaluated on the basis of a TBA index and the results achieved were collated in Table 8 . The rate of lipids oxidation was higher in the abdominal fat of the chickens fed the diet with DDGS addition as compared to the control birds $72 \mathrm{~h}$ after slaughter, after 7 days of storage in refrigeration conditions and 56 days of storage in a frozen state $\left(-18^{\circ} \mathrm{C}\right)$. 
Table 2

Effects of distillers dried grains on body weight of broiler chickens, $g$

\begin{tabular}{|c|c|c|c|c|c|}
\hline Feeding group & $\begin{array}{c}21 \text { days } \\
\text { LSM }\end{array}$ & $\begin{array}{c}35 \text { days } \\
\text { males } \\
\text { LSM }\end{array}$ & $\begin{array}{c}35 \text { days } \\
\text { females } \\
\text { LSM }\end{array}$ & $\begin{array}{c}42 \text { days } \\
\text { males } \\
\text { LSM }\end{array}$ & $\begin{array}{c}42 \text { days } \\
\text { females } \\
\text { LSM }\end{array}$ \\
\hline K & 1023.6 & $2384.3^{\mathrm{A}}$ & 1961.9 & $3085.8^{a}$ & 2503.9 \\
\hline $\mathrm{D}_{1}$ & 1005.1 & $2266.0^{\mathrm{Ba}}$ & 1948.3 & $2937.6^{b}$ & 2521.4 \\
\hline$D_{2}$ & 1013.8 & $2352.6^{a}$ & 1936.9 & 3048.4 & 2499.8 \\
\hline SEM & 9.0 & 30.1 & 34.0 & 46.7 & 36.8 \\
\hline
\end{tabular}

LSM: least squares means, SEM: standard error of the mean, ${ }^{\mathrm{A}, \mathrm{B}} P \leq 0.01,{ }^{\mathrm{a}, \mathrm{b}} P \leq 0.05$

Table 3

Performance of broiler chickens

\begin{tabular}{lccccc}
\hline $\begin{array}{l}\text { Feeding } \\
\text { group }\end{array}$ & Body weight, g & $\begin{array}{c}\text { Feed consumption, } \\
\text { kg/kg gain }\end{array}$ & $\begin{array}{c}\text { European } \\
\text { Yield Index }\end{array}$ & \multicolumn{2}{c}{$\begin{array}{c}\text { Mortality, \% } \\
\text { whole }\end{array}$} \\
\hline $\mathrm{K}$ & 2794.9 & 1.79 & 341 & 5.5 & 2.5 \\
sudden death syndrome & \\
$\mathrm{D}_{1}$ & 2729.5 & 1.78 & 346 & 3.0 & 1.25 \\
$\mathrm{D}_{2}$ & 2774.1 & 1.75 & 348 & 5.5 & 2.5 \\
\hline
\end{tabular}

Table 4

Results of slaughter analysis of broiler chickens, $\%$

\begin{tabular}{lccccccc}
\hline $\begin{array}{l}\text { Feeding } \\
\text { group }\end{array}$ & $\begin{array}{c}\text { Dressing } \\
\text { percentage }\end{array}$ & $\begin{array}{c}\text { Breast } \\
\text { muscle }\end{array}$ & $\begin{array}{c}\text { Leg } \\
\text { muscles }\end{array}$ & Gizzard & Heart & Liver & $\begin{array}{c}\text { Abdominal } \\
\text { fat }\end{array}$ \\
\hline $\mathrm{K}$ & 77.36 & 28.27 & 19.48 & 0.82 & 0.82 & 2.24 & 1.85 \\
$\mathrm{D}_{1}$ & 76.98 & 29.41 & 19.94 & 0.84 & 0.84 & 2.08 & 1.76 \\
$\mathrm{D}_{2}$ & 76.82 & 28.27 & 19.88 & 0.83 & 0.83 & 2.08 & 1.93 \\
SEM & 0.5 & 0.7 & 0.5 & 0.03 & 0.03 & 0.1 & 0.1 \\
\hline
\end{tabular}

Table 5

Chemical composition of chicken meat, $(\mathrm{g} / 100 \mathrm{~g}) \mathrm{n}=6$

\begin{tabular}{|c|c|c|c|c|c|c|c|c|}
\hline \multirow{2}{*}{$\begin{array}{l}\text { Feeding } \\
\text { group }\end{array}$} & \multicolumn{2}{|c|}{ Water } & \multicolumn{2}{|c|}{ Protein } & \multicolumn{2}{|c|}{ Fat } & \multicolumn{2}{|c|}{ Ash } \\
\hline & BM & LM & $\mathrm{BM}$ & LM & BM & LM & BM & LM \\
\hline K & 75.0 & $74.7^{\mathrm{A}}$ & 22.5 & $18.2^{\mathrm{B}}$ & 1.1 & $5.0^{B}$ & 0.9 & 1.3 \\
\hline $\mathrm{D}_{1}$ & 74.8 & $74.4^{\mathrm{B}}$ & 22.5 & $17.7^{c}$ & 1.1 & $6.2^{\mathrm{A}}$ & 0.9 & 1.2 \\
\hline$D_{2}$ & 74.7 & $73.4^{c}$ & 22.5 & $18.7^{\mathrm{A}}$ & 1.2 & $6.2^{\mathrm{A}}$ & 0.9 & 1.2 \\
\hline SEM & 0.132 & 0.043 & 0.098 & 0.047 & 0.047 & 0.033 & 0.061 & 0.019 \\
\hline
\end{tabular}

BM: breast muscles, LM: thigh muscles, $A, B, C P \leq 0.01$

Table 6

Physicochemical traits of chicken meat, $\mathrm{n}=6$

\begin{tabular}{lllccll}
\hline $\begin{array}{l}\text { Feeding } \\
\text { group }\end{array}$ & \multicolumn{2}{c}{$\mathrm{pH}$} & \multicolumn{3}{c}{ Water absorption, \% } & \multicolumn{2}{c}{ Thermal drip, \% } \\
\hline $\mathrm{K}$ & $\mathrm{BM}$ & $\mathrm{LM}$ & $\mathrm{BM}$ & $\mathrm{LM}$ & $\mathrm{BM}$ & $\mathrm{LM}$ \\
$\mathrm{D}_{1}$ & 6.0 & 6.3 & $35.3 \mathrm{a}$ & 42.7 & 2.8 & $6.5 \mathrm{a}$ \\
$\mathrm{D}_{2}$ & 6.0 & 6.3 & $34.7 \mathrm{a}$ & 39.4 & 2.6 & $6.4 \mathrm{a}$ \\
SEM & 5.9 & 6.3 & $31.0 \mathrm{~b}$ & 40.1 & 2.6 & $5.0 \mathrm{~b}$ \\
\hline
\end{tabular}

BM: breast muscles, LM: thigh muscles, ${ }^{a, b} P \leq 0.05$ 
Table 7

Fatty acid composition in the chicken abdominal fat, in $\mathrm{g} / 100 \mathrm{~g}, \mathrm{n}=6$

\begin{tabular}{lccccc}
\hline Feeding group & SFA & MUFA & PUFA & PUFA n-3 & PUFA n-6 \\
\hline K & 26.8 & 38.0 & 32.5 & 2.9 & 29.5 \\
D $_{1}$ & 27.3 & 38.1 & 32.2 & 2.9 & 29.3 \\
D $_{2}$ & 27.3 & 38.1 & 31.8 & 2.9 & 28.8 \\
SEM & 0.281 & 0.389 & 0.396 & 0.033 & 0.380 \\
\hline
\end{tabular}

SFA - 12:0, 13:0, 14:0, 16:0, 17:0, 18:0, 20:0, 22:0, MUFA - 14:1, 16:1, 17:1, 18:1, 20:1, PUFA n-3 - 18:3, PUFA n-6 - 18:2, 20:4

Table 8

Chemical changes in chicken abdominal fat during storage in different time, $\mathrm{n}=6$

\begin{tabular}{|c|c|c|c|}
\hline \multirow[t]{3}{*}{ Feeding group } & \multicolumn{3}{|c|}{ TBA index } \\
\hline & & & $-18^{\circ} \mathrm{C}$ \\
\hline & 3 days & 7 days & 56 days \\
\hline K & $0.28^{\mathrm{Bb}}$ & $0.33^{\mathrm{B}}$ & $0.38^{c}$ \\
\hline$D_{1}$ & $0.36^{A}$ & $0.49^{\mathrm{A}}$ & $0.69^{\mathrm{B}}$ \\
\hline $\mathrm{D}_{2}$ & $0.31^{\mathrm{Ba}}$ & $0.39^{\mathrm{B}}$ & $0.89^{\mathrm{A}}$ \\
\hline SEM & 0.007 & 0.011 & 0.009 \\
\hline
\end{tabular}

$A, B P \leq 0.01, a, b P \leq 0.05$

\section{Discussion}

The chemical composition of dried distillers grains greatly depends on the method of their production. Many researchers believe that wheat DDGS are characterised by a higher protein content (40.4-44.5\%) and a lower fat level (2.9-3.7\%) than the maize DDGS (28.2-30.3\% and $7.2-12.8 \%$, respectively). Crude fibre content in both products is comparable (7.0-7.6\%), but its composition is completely different. Wheat DDGS contain more soluble fibre fractions (non starch polysaccharides - NSP) than the maize DDGS (Nyachoti et al. 2005, Widyaratne \& Zijilstra 2007, Pedersen et al. 2007). When comparing the content of nutrients in dried distillers wheat grains with solubles applied in the experiment with results reported by Widyaratne \& Zijilstra (2007), we may state that they were characterised by a lower protein and ash content and simultaneously, contained more fat and crude fibre. Lysine content (lysine is the first limiting amino acid in feed containing dried distillers grains) and energetic value were also lower. It indicates the need for precise balancing of the formulations of feed mixtures with DDGS addition in respect of amino acid composition and metabolisable energy, and of their possible supplementation with synthetic amino acids.

Investigations on the possibility of applying cereal DDGS in poultry feeding have been conducted for many years. Waldroup et al. (1981) and Parson et al. (1983) showed that maize DDGS could replace $25-40 \%$ of soybean meal in the mixture without deteriorating production results. The progress achieved in the improvement of utility traits has, however, caused that such a high level of DDGS can no longer be applied. Batal \& Dale (2003) and Lumpkins et al. (2004) found that it was possible to add maize DDGS to feed mixtures for the chickens at the level of $6 \%$ in starter and at the level of $12-15 \%$ in grower and finisher mixtures without a negative influence on the growth of the birds and quality of their carcass. According to Świątkiewicz \& Koreleski (2003), the optimal contribution of dried distillers 
maize in feed mixtures for slaughter chickens amounted to $2 \%$ in the first and to $5 \%$ in the second rearing period. The chickens administered the mixtures with $10 \%$ addition of DDGS, were characterised by deteriorated body weight gains and feed conversion ratio. Thacker \& Widyaratne (2007) applied feed mixtures with different levels of wheat DDGS $(0,5,10,15$ and $20 \%)$ in chicken feeding. They showed that DDGS addition to feed (15\%) did not affect the production results. Also, Wang et al. (2007) stated that it was possible to use DDGS in the feed mixture for chickens in the quantities of up to $15 \%$ but under condition that the mixture was thoroughly balanced in respect of amino acid composition and metabolisable energy. Most of the authors suggested the necessity of conducting frequent physicochemical analyses of DDGS.

The results achieved in our experiment are consistent with the above-mentioned data and indicate the possibility of applying DDGS in the feed mixtures as a replacer of soybean meal without deteriorating production results of the chickens. In the case of the birds from $D_{1}$ group (a lower DDGS level), the improvement of rearing effectiveness was even recorded owing to a reduction of the mortality rate (from 5.5 to $3.0 \%$ ). In the practice of the commercial rearing of chickens, a mortality rate of up to $4 \%$ has been adopted as an admissible standard. It should also be emphasised that in the experimental groups administered the DDGS addition, values of the European yield index were somewhat higher (346 and 348) as compared to the control group (341). The European yield index is applied for comparative purposes, for the objective evaluation of production results, obtained under different management conditions of slaughter chickens, with different feeding systems and density of the birds (Brzóska 2007).

Results of analyses that show the impact of the type and level of a particular component addition not only on production results but also on dressing percentage of birds as well as on the quality of their meat and fat are of special significance to poultry meat producers while formulating the composition of feed mixtures. Dressing percentage and the share of the most valuable breast and leg muscles in carcass have a fundamental effect on the economic effectiveness of poultry meat production. First of all dressing percentage depends on nutrition, genetic material and slaughter age as well as on the method of carcass chilling. In the member states of the European Union it varies from $66 \%$ to $67 \%$ without consideration of edible offal whereas together with offal, it increases above $70 \%$. Dressing percentage and the participation of breast and leg muscles and of abdominal fat in the carcasses of control chickens and those fed the diet with DDGS were not statistically significantly different. It may, however, be mentioned that in the carcasses of the chickens from $D_{1}$ group, the participation of the breast muscles was somewhat higher (by ca. $4 \%$ on average) and that of the abdominal fat was lower (by ca. $5 \%$ ) as compared to the control group.

According to those results, it may be stated that the application of DDGS in feed mixtures for the chickens did not cause any significant changes in the proximate chemical composition and technological properties of the meat and also, in fatty acid profile of the abdominal fat. The proximate chemical composition of chickens meat was similar to the values reported by other authors (Pietrzak et al. 2005, 2006, Pisarski et al. 2006, Ristic et al. 2008, Szkucik et al. 2009), where the breast muscles contained $73.7-75.1 \%$ of water, $0.6-1.4 \%$ of fat, $22.2-23.4 \%$ of protein and $1.0-1.3 \%$ of ash, on average. In turn, the leg muscles contained: $74.2-75.4 \%$ of water, $18.5-19.7 \%$ of protein, $4.6-7.2 \%$ of fat and $1.0-1.1 \%$ of ash. The breast muscles 
in contrast to the leg muscles contain less fat, and this is a genetically-determined trait. Although it lowers their sensory values, it improves their dietetic value. The technological value of meat and indirectly the quality of the manufactured products is affected, inter alia, by $\mathrm{pH}$ value, water holding capacity and the level of thermal drip. The leg muscles were characterised by a higher water holding capacity than the breast muscles, which is due to their higher $\mathrm{pH}$ value. On the other hand, the quantity of thermal drip during heat treatment of leg muscles was almost twice as high as in breast muscles. Leg muscles contain more collagen which, after thermal treatment, keeps water weaker as compared to the muscle tissue proteins. A similar tendency was recorded in the studies of Pietrzak et al. $(2005,2006)$, where relatively small losses of weight during heat treatment (especially of breast meat) were recorded because the heating of the samples was conducted in moderate conditions.

When analysing the results of determinations of fatty acid profile in abdominal fat of the chickens, it was observed that the percentage contribution of saturated (SFA) and monounsaturated (MUFA) fatty acids was considerably lower and that of PUFAs was higher in comparison to the values reported in the earlier publications (Pietrzak et al. 2005, 2006). On the other hand, similar results were obtained by Pisarski et al. (2006). According to Pikul (1996), fatty acid composition in the muscles and abdominal fat of the poultry depends on many factors, including feed composition. Poultry may synthesise saturated and monounsaturated fatty acids from non-fat feeds. They are mainly palmitic acid and stearic acid as well as palmitoleic and oleic acids. Polyunsaturated acids, such as linoleic (n-6) and linolenic (n-3) acids, are not synthesised by the poultry and need be supplied for the birds in the diet. A high content of polyunsaturated fatty acids in meat and fat of the poultry increases its nutritional value as compared to pork or beef meat. PUFA n-3 fatty acids are extremely important. It was revealed that a daily intake of $0.3-1.0 \mathrm{~g}$ of the mentioned acids protects a man from heart coronary disease. Furthermore, they have a therapeutic and prophylactic effect on such diseases as arthritis and cancer of breast and pancreas (Lopez-Ferrer et al. 2001).

A high level of unsaturated fatty acids in poultry fat may, however, affect unfavourably its stability. Rapid oxidative changes of lipids and the resultant oxidation products may lower quality traits of poultry meat and meat products and also considerably shorten their shelflife (Pikul 1996). In the earlier studies Pietrzak et al. (2005) showed that oxidative changes occurred much quicker in the abdominal fat of COBB chickens fed with an antibiotic growth stimulant as compared to the control group. At the same time their fat contained more unsaturated fatty acids (linoleic acid in particular) and less saturated fatty acids. Such a dependency was not observed in the reported experiment. The composition of fatty acids in the abdominal fat of the chickens from all feeding groups was comparable, whereas in the abdominal fat of the chickens fed with the DDGS addition, the rate of lipids oxidation was higher as compared to the control group $72 \mathrm{~h}$ after slaughter as well as during the storage in the refrigeration conditions and in the frozen state.

In conclusion, the results of the study indicate that DDGS may successfully constitute a good energy-protein ingredient in feed mixtures for broiler chickens. The application of wheat DDGS in poultry nutrition is, therefore, a reasonable method for their disposal. 


\section{References}

AOAC (1995) Official methods of analysis of AOAC international. AOAC, Washington, USA

Batal A, Dale N (2003) Mineral composition of distillers dried grains with solubles. J Appl Poult Res 12, 400-403

Brzóska $F$ (2007) [Effectivity of organic acids and synbiotic in chicken-broiler feeding]. Med Weter 63, 831-835 [in Polish]

Brzóska F (2009) [Is it possible to replace GMO protein with other protein sources? (part I)]. Wiadomości Zoot R. XLVII, 1, 3-9 [in Polish]

European Table (1989) European Table of energy values for poultry feedstuffs. WPSA Wageningen, The Netherlands

Polish Standard PN-ISO 2917 (2001) [Meat and meat products. Determination of meat pH], Warsaw, Poland [in Polish]

Polish Standard PN-ISO 5508 (1996) [Animal and vegetable fats and oils - Analysis by gas chromatography of methyl esters of fatty acids], Warsaw, Poland [in Polish]

Polish Standard PN-ISO 5509 (1996) [Animal and vegetable fats and oils - Preparation of methyl esters of fatty acids] [in Polish]

Koreleski J, Świątkiewicz S (2006) [Nutritive value and use of biofuel by products in poultry nutrition]. Wiadomości Zoot 44, 29-37 [in Polish]

Lopez-Ferrer S, Baucells MD, Barroeta AC, Grashorn MA (2001) n-3 enrichment of chicken meat. 1. Use of very long-chain fatty acids in chicken diets and their influence on meat quality: fish oil. Poult Sci 80, 741-752

Lumpkins BS, Batal AB (2005) The bioavailability of lysine and phosphorus in distillers dried grains with solubles. Poult Sci 84, 581-586

Lumpkins BS, Batal AB, Dale NM (2004) Evaluation of distillers dried grains with solubles as a feed ingredient for broilers. Poult Sci 83, 1892-1896

Martinez Amezcua C, Parsons CM, Noll SL (2004) Content and relative bioavailability of phosphorus in distillers dried grains with solubles in chicks. Poult Sci 83, 971-976

Min YN, Liu FZ, Wang Z, Coto C, Cerrate S, Costa FP, Yan F, Waldroup PW (2008) Evaluation of distillers dried grains with solubles in combination with glycerin in broiler diets. Int J Poult Sci 7, 646-654

Nyachoti CM, House JD, Slominski BA, Seddon IR (2005) Energy and nutrient digestibilities in wheat dried distillers' grains with solubles fed to growing pigs. J Sci Food Agric 85, 2581-2586

Parson CN, Baker DH, Harter JM (1983) Distillers dried grains with solubles as protein source for chick. Poult Sci 62, 2445-2451

Pedersen C, Boersma MG, Stein HH (2007) Digestibility of energy and phosphorus in ten samples of distillers dried grains with solubles fed to growing pigs. J Anim Sci 85, 1168-1176

Pietrzak D, Mroczek J, Antolik A, Michalczuk M, Niemiec J (2005) [Influence of growth stimulators added to feed on the quality of meat and fat in broiler chickens]. Med Weter 61, 553-557 [in Polish]

Pietrzak D, Mroczek J, Adamczak L, Wojda Ł, Niemiec J (2006) The effect of an increased supplement B-group vitamins on the composition and properties of chicken meat and fat. Anim Sci Supplement 1, 156-157

Pikul J (1996) [Lipids in poultry meat]. Gosp Mięsna 48, 28-34 [in Polish]

Pisarski RK, Szkucik K, Pijarska I, Malec H (2006) [Carcass characteristics, chemical composition and sensorial evaluation of meat from broiler chickens fed hull-less barley]. Med Weter 62, 74-76 [in Polish]

Ristic M, Freudenreich P, Damme K (2008) [The chemical composition of poultry meat]. Fleischwirtschaft 88, 124-126 [in German]

Shahidi F (1990) The 2-thiobarbituric acid (TBA) methodology for the evaluation of warmed - over flavour and rancidity in meat products. Proc 36th ICoMST, Havana, 1008

Świątkiewicz S, Koreleski J (2003) [An attempt to use dried corn distillers grains as a component of diets for broiler chickens]. Rocz Nauk Zoot 30, 367-379 [in Polish] 
Świątkiewicz S, Koreleski J (2007) [Quality of egg shells and bones in laying hens fed a diet containing distillers dried grains with solubles]. Med Weter 63, 99-103 [in Polish]

Świątkiewicz S, Koreleski J (2008) The use of distillers dried grains with solubles (DDGS) in poultry nutrition. World Poult Sci J 64, 257-267

Szkucik K, Pisarski RK, Paszkiewicz W, Pijarska I (2009) [Carcass quality, chemical composition and sensory characteristics of meat from broiler chickens fed growing/finishing feeds of lowered energy value]. Med Weter 65, 184-187 [in Polish]

Thacker P, Widyaratne G (2007) Nutritional value of diets containing graded levels of wheat distillers grains with solubles fed to broiler chicks. J Sci Food Agric 87, 1386-1390

Waldroup PW, Owen JA, Ramsey BL, Whelchel DL (1981) The use of high levels of dried distillers grains plus solubles in broiler diets. Poult Sci 60, 1479-1484

Wang Z, Cerrate S, Coto C, Yan F, Waldroup PW (2007) Utilization of distillers dried grains with solubles (DDGS) in broiler diets using a standardized nutrient matrix. Int J Poult Sci 6, 470-477

Widyaratne G, Zijlstra R (2007) Nutritional value of wheat and corn distiller's dried grain with solubles: Digestibility and digestible contents of energy, amino acids and phosphorus, nutrient excretion and growth performance of grower-finisher pigs. Can J Anim Sci 87, 103-114

Wierbicki E, Tiede MG, Burrell RG (1962) Determination of meat swelling as a method for investigating the water binding capacity of muscle proteins with low water-holding forces. Fleischwirtschaft 14, 951-958

Received 7 November 2012, accepted 20 March 2012.

Corresponding author:

Monika Łukasiewicz

email: monika_lukasiewicz@sggw.pl

Faculty of Animal Science, Warsaw University of Life Sciences, Ciszewskiego 8, 02-786 Warsaw, Poland 